\title{
PENGARUH TEKNOLOGI INFORMASI TERHADAP KINERJA PERUSAHAAN: KEJELASAN PERAN SEBAGAI VARIABEL MODERATING (Studi Empiris pada BPR di Kabupaten Banyumas)
}

\author{
Dona Primasari \\ Universitas Jenderal Sudirman \\ e-mail : dona_primasari@yahoo.com
}

ABSTR.ACT

\begin{abstract}
The main objective of this study is to examine the infuence of mformation techology and Role Clarity to Corporate Performance. Role clarity as an moderating variable. This research represents the empirical test which used sensus sampling technics in data collection. Data were collected using a survey 120 respondents data was anavized by SPPS Ver 18. The result found that received one hypothesis and rejected the other:
\end{abstract}

Kevwords: Information Technology; Role Clarin, Corporate Performance

\section{PENDAHULUAN}

Perkembangan teknologi informasi sedikit banyak sangat mempengaruhi dunia perindustiran, adanya perkembangan teknologi nformasi saat ini banyak memberikan kemudahan gada berbagai aspek kegiatan bisnis (Mc.Leoad R.J., 1997, Indriantoro, 2000 dalam Hilendri 2006). Teknologi informasi menupakan bagian dari sistem informasi dan teknologi informasi merujuk pada teknologi yang digunakan dalam menyampaikan maupun mengolah informasi (Aji, 2005). Teknologi informasi telah membawa perubahan yang sangat mendasar bagi organisasi baik swasta maupun organisasi publik. Oleh karena itu. teknologi informasi menjadi staru hal yang sangat penting dalam menentukan daya saing dan kemampuan perusahaan untuk meningkatkan kinerja bisnis di masa mendatang. Sumber daya teknologi informasi menjadi sebuah pertimbangan baik itu bagi para manajer dan konsultan, dalam menentukan keberhasilan perusahaan di masa mendatang.
Kejelasan peran akan meningkatkan motivasi intrinsik untuk bekerja, hal ini dapat meningkatkan harapan sebuah usaha menuju terbentuknya suatu kinerja maksimal dan kinerja tersebut akan memberikan suatu informasi hasil akhir (Jackson dan. Schuler 1985: Tubre dan Collins, 2000). Dengan adanya kejelasan peran akan mempengaruhi kinerja pegawai sehingga secara tidak langsung akan mempengarthi kinerja perusahaan

Yang menjadi pokok utams permasalahan dalam penelitian yang telalt dilakukan adalah

1. Apakali teknologi informasi mempunyai pengaruh terhadap kinerja perusahaan?

2. Apakah kejelasan peran memoderasi pengerul teknologi miormasi akuntansi terhadap kinerja perusahaan?

Adapun tujuan dari penelitian ini adaiah

a. Menganalisis secara empiris mengenai pengaruh teknolog: informasi akuntansi terhadap kinerja penusahaan. 
b. Menganalisis secara empiris mengenai pengaruhteknologi informasi terhadap kineria perusahaan yang dimoderasi oleh kejelasan peran

\section{REVIEW LITERATUR DAN HIPOTESIS}

Kerangka pemikiran penelitian ini adalah sebagai berikut :

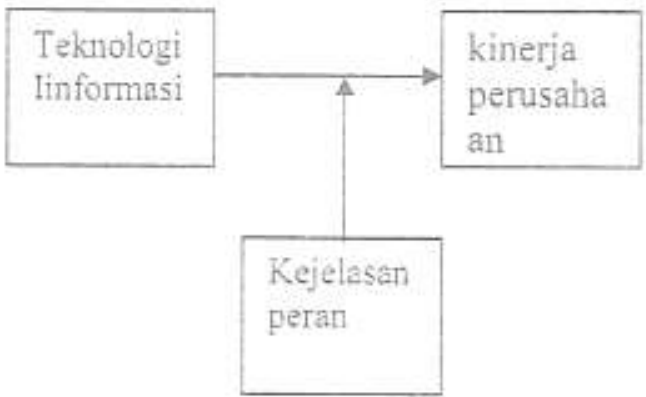

Gambar

Kerangka Pemikiran

\section{Hipotesis}

hipotesis yang dikemukakan adalah :

$\mathrm{H} 1$ = Teknologi Informasi mempunyai pengarth positif terhadap kinerja perusahaan

$\mathrm{H} 2$ = kejelasan peran memoderasi pengaruh teknologi informasi terhadap kinerja perusahaan.

\section{METODE PENELITIAN}

Populasi dalam penelitian ini adalah para manajer yang bekerja pada Bank Perkreditan Rakyat (BPR) di Kabupaten Banyumas, Adapun sampelyang digunakan adalah manajer keuangan. manajer personalia, manajer administrasi. teknologi informasi, dan manajer pemasaran. Penggunaan manajer sebagai sampel dalam penelitian ini karena pertama, BPR manajer bank memiliki persepsi yang borbeda mengenai penerapan teknologi informasi, kejelasan peran, strategi dan kinerja dan manajer yang memimpin divisi dalam organisasi juga bertindak sebagai pimpinan divisi yang diberi twewenang dan tanggung jawab terhadap kebijakan pengaturan bisnis dan informasi perusainaan.

Teknik pengambilan sampel dalam penelitian ini dilakukan dengan cara sensus sampling yaitu teknik penentuan sampel dengan mengambil semua sampel yang ada. Hal ini dilakukan karena jumlah BPR di Kabupaten Banyumas hanya terdapat 31 BPR, untuk itu digunakan metode sensus dengan mendatangi langsung semua BPR yang ada di kabupaten Banyumas. Adapun persyaratan penentuan sampel adalah manajer divisi yang ada pada masing-masing BPR di Kabupaten Banyumas

\section{Prosedur Pengumpulan Data}

Kuesioner diantar langsung ke masingmasing BPR. Dart 155 buah kuesioner yang diantar, hanya 120 buah kuesioner yang kembali. $\mathrm{Hal}$ ini disebabkan karena sebagian BPR tidak bersedia dijadikan sampel dengan alasan mengaiami ksbangkrutan, sedang dalan proses audit dan ada juga yang pindah alamat șehingga tingkat respon tate pengembalian kuesioner hanva $77,4 \%$.

Kuesioner didesain terdiri dari dua bagian. Bagian pertama, terdiri dari instrumen pertanyaan yang menkonstruksi variabel penelitian. Bagian pertama ini berist pertanyaan dengan jawaban menggunakan skala Likert (1 sampai 5), Data penelitian yang dibutuhkan terdiri dari data primer dalam bentuk persepsi responden. Bagian kedua berisi deskripsi responden. merupakan uraian responden secara demografis.

\section{Teknik Analisis}

Uji Kualitas Data

Menurut Hair et al (1995) kualitas data yang dihasilkan dari penggunaan instrumen penelitian depat dievaluasi melalui uji reliabilitas dan validitas. Lji tersebut masing-masing untuk mengetahui konsistensi can akurasi data yang dikumpulkan dari penggunaan instrumen. Ada 
- prosedur yang dilakukan untuk mengukur tuabilitas dan validitas data, yaitu: uji konsistensi - temal terhadap jawaban responden atas estrumen penelitian dan uji validitas konstruk oengan cara mengkorelasikan antara skor masing-zsing item dan skor totainya. Keterangan dari ctua uji kualitas data adalah sebagai berikut:

1. Uji konsistensi intemal (reliabilitas) ditentukan dengan koefisien crorbach alpha. Suatu konstruk atau instrumen dikatakan reliabel jika memberikan nilai cronbach alpha di atas 0.60 (Nunnally. 1967 dalam Imam, 2005).

2. Uji homogenitas data (validitas) dengan uji person conrelation. Jika hasilnya signifikan maka data dikatakan valid.

\section{Uji Normalitas}

Uji nomalitas bertujuan untuk menguji zzakah dalam model regresi, variabel pengganggu mat residual memiliki distribusi normal. Seperti Aketahui bahwa tiji tdan F mengasumsikan bahwa - ilai residual mengikuti distribusi nomal. Kalau ssumsi ini dilanggar maka uji statistik menjadi zdak valid untuk jumlah sampel yang kecil. Salah satu uji statistik yang dapat digunakan untuk menguji normalitas residual adalah uji statistik -on-parametrik Kolmogorov-Smimov (K-S).

\section{tji Asumsi Klasik}

Sehubungan dengan penggunaan metode regresi berganda (multiple regression) maka perlu dilakukan pengujian asumsi klasik yang terdapat dalam regresi berganda sebagai berikut:

a. Uji Multikolinieritas

Uji multikolonieritas berrujuan untuk menguji apakah terdapat korelasi antar variabel independen pada model regresi (Imam. 2002). Uji ini dapat melihat besaran nilai VIF dan volerance. Pedoman yang digunakan untuk suatu model regresi yang bebas multikolonieritas adaiah nilai VIF semua variabel independen dibawah nilai 10 dan nilai tolerance di atas 0.1 (Hair. 1998).

\section{b. Uji Autokeretasi}

Uji autokorelasi bertujuan apakah dalam model regresi linear terdapat korelasi antara kesalahan pengganggu padá periode t dengart kesalahan pada periode $t-1$ (sebelumnya) (Imam, 2002). Lji ini dilakukan dengan melihat hasil Durbin Watson:

1) jika $d<d_{\text {L }}$ atau $d>\left(4-d_{2}\right)$ maka terdapat entokorelasi.

2) jika d terletak: antara d, dan (t-d, ) maka tidak ada autokorelasi.

3) jika $d$ terletak antara $d$ dan $d$ atau diantara (4-d.) dan (4-d.) maka tidak menghasilkan kesimpulan yang pasti.

c. Ufi Heteroskedastisitas

Uji heterokedastisitas dilakukan untuk menguji apakah dalam modei regresi terjadi ketidaksamaan varian dari residuai satu pengamatan ko pengamatan yang lain. Jika varian dari residual pengamatan yang lain tetap, maka disebut homokedastisitas, Niodel regresi yang baik adalah homokedastisitas atau tidak terhadi heterokedastisitas (Imam. 2002). uji heterokodestias dilakukan dengan uji park yairu dengan membuat model regresi yang menunjukkan hubungan antara nila! absolut residual (e) sebagai variabel dependen dengan variabel independen-tiya.

\section{Uji Hipotesis}

Analisis statistik yang digunakan adalah analisis regresi sederhana dan berganda sebagai model yang memprediksi hubungan kausal antara variabel dependen dengan beberapa variabel independen. Regresi linear sederhana untuk menguji hubungan antara tektologi infomasi akuntansi dengan kinerja perusahaan dan menguji hubungan variabel moderating (kejelasan peran) dengan kineria perusahaan. Hoderated regression analysis (MRA) digunakan untuk menentukar. hubungan interaksi antara tiga variabel oleh satu variabel sebagai variabel moderating (Nunnally, 1994). Persamaan statistika yang digunakan adalah sebagei berikut 
1. $\mathrm{KP}=\mathrm{a}+\mathrm{b} 1 \mathrm{Tl}-\mathrm{e}$

2. $\mathrm{KP}=\mathrm{a}+\mathrm{b} 1 \mathrm{TI}+\mathrm{b} 2 \mathrm{KPe}+\mathrm{b} 3 \mathrm{TI}^{* k} \mathrm{KPe}+\mathrm{e} \mathrm{(2)}$

Tabel 1

\begin{tabular}{|c|l|c|c|c|}
\hline No & Variabel & $\begin{array}{c}\text { Kisaran } \\
\text { Korelasi }\end{array}$ & $\begin{array}{c}\text { Signi- } \\
\text { fikansi }\end{array}$ & Keterangan \\
\hline 1 & $\begin{array}{l}\text { Teknoiogi } \\
\text { informasi }\end{array}$ & $\begin{array}{c}0.336^{* *}- \\
0.689^{* *}\end{array}$ & 0.001 & Valid \\
\hline 2 & $\begin{array}{l}\text { Kejelasan } \\
\text { peran }\end{array}$ & $\begin{array}{c}0,391^{* *} \\
0,781^{* *}\end{array}$ & 0.001 & Vilid \\
\hline 3 & $\begin{array}{l}\text { Kinerja } \\
\text { perusahaan }\end{array}$ & $\begin{array}{c}0.260^{* *} \\
0.820^{* *}\end{array}$ & 0.001 & Valid \\
\hline
\end{tabular}

Sumber : data diolah 2012

Dimana:

$$
\begin{array}{ll}
\text { P } & =\text { Kinerja Perusahaan } \\
\text { TI } & =\text { Telnologi Informasi } \\
\text { Kpe } & =\text { Kejclasan Peran } \\
\text { a } & =\text { intercept } \\
e & =\text { error }
\end{array}
$$

Jika variabel Kpe merupakan variabel moderator, maka koefisien b3 harus signifikan pada 0.05 atau 0.10 .

\section{HASIL PENELITIAN DAN PEMBAHASAN}

\section{Uji Kualitas Data}

Berdasarkan uji reabilitas dan validitas data diketahui bahwa data dalam penelitian adalah valid dan reliabel

Tabel 2

Hasil Lji reliabelitas dan validitas

\begin{tabular}{|c|l|c|c|}
\hline No. & Variabel & $\begin{array}{c}\text { Nilai } \\
\text { Cronbach Alpha }\end{array}$ & Keterangant \\
\hline 1 & $\begin{array}{l}\text { Teknologi } \\
\text { Infonnasi }\end{array}$ & 0.674 & Reliabel \\
\hline 2 & Kejelasas peran & 0.683 & Reliabel \\
\hline 3 & $\begin{array}{l}\text { Kinerja } \\
\text { perusahaan }\end{array}$ & 0,637 & Reliabel \\
\hline
\end{tabular}

Sumbet : data diolah 2012

\section{Uji Normalitas}

Berdasarkan hasil analisis data dengan bantuan software SPSS for Windows. Variabel dinyatakan menyebar dengan normal jika hasil uji kolmogorov smimov standarized residual menunjukkan jika nilai assympatic significant (2-tailed) $>$ alpha (0.05). Pada hasil output dapat diketahui bahwa nilai Kolmogorov Smimov test sebesar 0.898 , sedangkan nilai asymp. sig. (2-tailed) untuk instandardized variable sebesar 0.895 lebih besar dari nilai a yairu 0,05 , sehingga dapat disimpulkan bahwa data yang digunakan berdistribusi normal.

Uji Asumsi Klasik

\section{a. Uji Multikolinearitas}

Dari hasil uji Variance Infiation Factor (VIF) dengan bantuan soffware SPSS for Windows, diketahui nilai VIF variabel teknologi informasi sebesar 1.876 dan nilai VIF variabel kejelasan peran sebesar 1.211. masing-masing lebih kecil dari 5 , sehingga dapat disimpulkan tidak ada multikolinearitas di antara variabel bebas dalam model regresi.

\section{b. Uji Autokorelasi}

Berdasarkan hasil uji Durbin-Watson dengan bantuan software SPSS for Windows yang telah dilakukan, diperoleh nilai Durbin-Watson sebesar 1.809. Nilai tersebut dibandingkan dengan nilai Durbin Watson tabel untuk $\mathrm{n}=57$ dan $k=4$ dengan ( $a$ ) 0.05 atau $5 \%$. maka nilai d $=1,72$ dan $d_{2}=1,41$. Jadi nilai uji Durbin Watson berada di antara d, dan $4-d$. Hal ini merupakan bukti tidak adanya autokotelasi positif maupun negatif.

\section{c. Uji Heteroskedastisitas}

Berdasarkan uji Park pada lampiran. yaitu dengan membuat model regresi yang menunjukkan hubungan antara nilai absolut residual (e) sebagai variabel dependen dengan variabel independen-nya $(\mathrm{X} . \mathrm{X} .$.$) , diperoleh nilai$ signifikansit variabel nilai signifikansi t variabel $\mathrm{X}$ sebesar 0.889 dan nilai signifikansi $t$ variabel $X_{\text {z }}$ sebesar 0.359 masing-masing lebih besar dari nilai a sebesar 0.05 . Berdasarkan bukti tersebut, maka dapat disimpulkan bahwa tidak terdapat heteroskedastisitas dalam model regresi. 


\section{Uji Hipotesis}

Uji hipotesis dilakukan untuk menjawab masalah penelitian yang dirumuskan sebelumnya.

\section{a. Teknologilnformasi Berpengaruh Terhadap} Kinerja Perusahaan (H1)

Pengujian hipotesis I dilakukan dengan melihat interaksi antara variabel teknologi informasi dengan kinerja perusahaan (persamaan 1).

Adapun hasil pengujian menunjukkan besarnya adjusted $\mathrm{R}^{2}$ adalah 0,556 , hal ini berarti $55.6 \%$ variasi kinerja perusahaan dapat dijelaskan oleh variasi dari variabel teknologi informasi, sedangkan sisanya $44,4 \%$ dijelaskan oleh sebabsebab yang lain di luar model. Dari model regresi tampak variabel teknologi informasi signifikan pada 0,05 , hal ini berarti bahwa variabel kinerja perusahaan dipengaruhi olch teknologi informasi.

b. Kejelasan peran Memoderasi teknologi informasi Terhadap Kinerja perusahaan ( $\mathrm{H} 2)$.

Pengujian hipotesis 2 dilakukan dengan uji interaksi atau sering disebut dengan Moderated Rgression Analysis (MRA) yang merupakan aplikasi khusus regresi berganda linear dimana dalam persamaan regresinya mengandung unsur interaksi (perkalian dua atau lebih variabel independen). Hasil pengujian hipotesis 2 menunjukkan besannya adjusted $\mathrm{R}^{\text {: }}$ adalah 0,549 . $(54,9 \%)$, hal ini berarti. $54,9 \%$ variasi Kinerja perusahaan dapat dijelaskan oleh variasi variabel independen teknologi informasi. kejelasan peran, dan MDIIKPe (TI*KPe), sedangkan sisanya $45,1 \%$ dijelaskan oleh sebab-sebab lain di luar model. Dari uji satatistik F diperoleh sebesar 49,346 dengan tingkat signifikansi 0,00 jauh lebih kecil dari 0,05 , sehingga model regresi dapat digunakan untuk memprediksi Kinerja Manajerial petusahaan dapat dikatakan bahwa teknologi informasi, kejelasan peran. dan MDIIKPe (TI*KPe) secara bersama-sama berpengaruh terhadap Kinerja perusahaan. Sedangkan dari uji parameter individual diperoleh hasil variabel teknologi informmasi berpengaruh secara signifikan terhadap Kineria perusahaan karena tingkat signifikansinya di bawah 0,05 dan variabel MDTIKPe yang merupakan interaks: antara teknologi informasi dan kejelasan peran tidak signifikan. Sehingga dapat diartikan bahwa variabel kejelasan peran bukan merupakan variabel moderating atau tidak memoderasi hubungan antara teknologi informasi dan Kineria Perusahaan

\section{Pembahasan.}

Teknologi Informasi berpengaruh terhadap Kinerja Perusahaan

Teknologi informasi terbukti berpengaruh terhadap kinerja perusahaan. Hasit penelitian ini sesuai dengan penelitian yang dilakukan sebelumnya oleh Hilendri (2006) dimana pengaruh tersebut mengindikasikan bahwa dengar pengelolaan sumber daya teknologi infomasi yang dilakukan oleh perusahaan dalam hal ini infrastruktur. strategi, sumber daya manusia dan vendor akan meningkatkan pemahaman perusahaan terhadap produk. pelanggan, dan manajerial sehingga dengan adanya pemahaman tersebut. perusahaan mampu meningkatkan kinerja perusahaan.

Kejelasan Peran Memoderasi hubungan Teknologi Informasi dan kinerja perusahaan

Hasil penemuan hipotesis kedua tidak sesuai dengan hipotesis yang diajukan. Penolakan terhadap hipotesis kedua mengindikasikan bahwa Kejelasan Peran tidak cukup memberikan bukti dapat mempengaruhi teknologi infomasi dan kinerja perusahaan. Penelitien ini mendukung penelitian sebelumnya mengenai kejelasan peran (Rahman,2006). Manajer didalam tugasnva diberi wewenang dan tanggung jawab serta targettarget yang harus dicapai oleh atasannya, tetapi 
wewenang dan tanggungjawab yang berlebihan akan membuat manajer tersebut merasa di eksploitasi dari pada diberdayakan.

\section{KESIMPULAN DAN SARAN}

Berdasarkan hasil penelitian ini, dapat diambil kesimpulan bahwa:

1. Teknologi Informasi terbukti berpengaruh terhadap kinerja perusahaan.

2. Kejelasan peran tidak terbuktimemoderasi hubungan antara teknologi informasi dan kinerja perusahaan.

Variabel penelitian ini hanya sebagian dari faktor-faktor yang mempengaruhi kinerja Perusahan. Penelitian selanjutnya diharapkan bisa menambah faktor-faktor lainnya seperti pengendalian intemal, komitmen organisasi atau budaya organisasi.

Penelitian hanya melihat interaksi antara variabel independen terhadap dependen, tetapi tidak menguji pengarulnyya secara positif atau negatif. Penelitian yang akan datang hendaknya menguji lebih lanjut tentang hubungan secara positif atau negatif dari variabel-variabel independen terhadap variabel dependen. Sehingga akan lebih terlihat hubungan dari variabel independen dan variabel dependen.

\section{DAFTAR PUSTAKA}

Afni, Nur. 2009. Pengaruh Kapasitas Sumber Daya Manusia, Pemanfaatan Tehnologi Infomasi dan Pengendalian Intem Akumansi terhadap Ntlai Informasi Pelaporan Keuangan Pemerintah Daerah. Skripsi UNSOED, Purwokerto. Tidak Untuk Dipublikasikan.

Aji, Supriono. 2005. Pengantar tehnologi Informasi. Semarang: Salemba Infotik.

Alimbudiono, Ria Sandra \& Fidelis Arastyo Andono, 2004. Kesiapan Sumber Daya Manusia Sub Bagian Akumtansi Pemerintah Daerah " MYZ" dan
KaitannaDenganPertanggungiawaban Keuanzan Dateah Kepada Hasyarakat: Renumgan Bagi Akunan Pendidik. Jumal Akuntansi dan Keuangan Sektor Publik. Vol. 05 No. 02. Hal. 18-30.

Chong, V.K. 1997. "Strategic Choices, Envirommental Uncertainty And Managerial Performance: A Note On The Intervening Role of Management Accounting Systems", Accoumting And Business Research, Vol, 27, No.24

Govindarajan. V. 1986. Impact of participation in the budgerant process on managerial attindes andperfomance : wiversalistic and contingency perspectives. Decision Sciences, 17 , pp. 496-516.

Hilendri, Baiq Anggun. 2007. "Pengaruh Information Technology Relatedness terhadap Kinerja Perusahaan dengan Knowledge Hanagement Capability sebagat lariabel Intertening". Tesis Magister Sains Akuntansi Undip Semarang (Tidak Dipublikasikan

Oktavianus Pasoloran. 2002, "Pengaruh Ketidapastian Linghungan Terhadap Hubmgan Antara Karakteristik Sistem Penganggaran Dengan Kinerja Manajerial Pada Pertusahaan Inatustri Makassal", Tesis Magister Sains Akuntansi Undip Semarang (Tidak Dipublikasikan)

Primasari. Dona. 2011. "Pengaruh Sistem Injomast Atumansi terhadap Kinerja Manajerial dengan tiga variabel moderating". Jumal Akuntansi dan Keuangan Universitas Muhammadiyah Magelang.

Rahman. Syaiful.2006. "Pengarih' Sistem Pengukuran Kinerja terhadap Kejelasan Peran, Pemberdaraan Psikologis dan Kinerja Manajerial". Tesis Magister Sains Akuntansi Undip Semarang (Tidak Dipublikasikan

Sukma Lesmana, 2001. "Pengaruh Sistem 
Kontrol Akuntansi Terhadap Kinerja Perusahaan Dengan Variabel Moderating Ketidakpastian Lingkungan Dan Strategi Kompetitif', Junal Ekonomi Dan Bismis Vol.1

Uma Sekaran, 2000, Research Methods For Business, John Wiley And Sons. Inc. Third Edition

Yubiharto, 2003, "Pengamh Ketidakpastian
Lingkungan DanStrategiBisnis Terhadap KinerjaKanajertalDenganKarakteristik Sistem Akunansi Manajemen Sebagai Fariabel Intervening". Tesis Magister Sains Akuntansi Undip Semarang (Tidak Dipublikasikan) 